\title{
WYNIKI ANALIZ SPEKTROMETRYCZNYCH DWÓCH DZBANÓW FENICKICH Z KOLEKCJI GOŁUCHOWSKIEJ
}

\section{RESULTS OF THE X-RAY FLUORESCENCE SPECTROMETRY ANALYSES OF TWO PHOENICIAN JUGS FROM THE GOŁUCHÓW COLLECTION}

\author{
Michat Krueger \\ Instytut Archeologii, Uniwersytet im. Adama Mickiewicza w Poznaniu \\ ul. Umultowska 89D, 61-614 Poznań, Poland \\ krueger@amu.edu.pl \\ Inga Gtuszek \\ Instytut Archeologii, Uniwersytet Mikołaja Kopernika \\ ul. Szosa Bydgoska 44/48, 87-100 Toruń, Poland \\ inga.gluszek@umk.pl
}

\begin{abstract}
This paper presents results of the spectrometric analyses of two Phoenician jugs from the Gołuchów collection. A non-invasive portable X-ray fluorescence spectrometer (pXRF) has been used to determine the chemical composition of the jugs. The aim of this work was to add new results to a database of spectrometric data of Phoenician pottery from central and western Mediterranean. Good agreement obtained between the chemical results of the two jugs suggest that they could have been made from the same clay.
\end{abstract}

KEY WORDS: X-ray fluorescence spectrometry analyses, Phoenician jugs, Gołuchów collection

\section{WPROWADZENIE}

Kolekcja gołuchowska była jednym z najbogatszych zbiorów ceramiki starożytnej znajdujących się w rękach prywatnych na terenach ziem polskich pod zaborami i doczekała się licznych opracowań1. Początki zbioru wiążą się z osobą Jana Działyńskiego,

\footnotetext{
${ }^{1}$ Literatura dotycząca kolekcji gołuchowskiej zgromadzonej przez Izabelę z Czartoryskich Działyńską jest bardzo bogata. Jedną z najbardziej istotnych publikacji jest artykuł Teresy Jakimowicz „Od kolekcji
} 
właściciela zamku w Gołuchowie oraz jego żony księżniczki Izabeli z Czartoryskich Działyńskiej, którzy w drugiej połowie XIX wieku zgromadzili wiele artefaktów pochodzących z terenów basenu Morza Śródziemnego. Największą sławą cieszyła się kolekcja waz greckich, budząca żywe zainteresowanie tak znanych archeologów klasycznych, jak na przykład prof. John Davidson Beazley (Beazley, 1928). Obecnie kolekcja jest rozproszona i tylko jej niewielka część znajduje się w zamku gołuchowskim. Wśród zabytków eksponowanych w Zamku w Gołuchowie Oddział Muzeum Narodowego w Poznaniu, znalazły się dwa dzbany będące tematem niniejszego artykułu ${ }^{2}$.

Te niepozorne przedmioty zdradzają ciekawość właścicieli Gołuchowa do nabywania reprezentatywnych zabytków dla mniej znanych cywilizacji śródziemnomorskich, a współczesnym badaczom dostarczają wyjątkowej okazji do badań materiału będącego rzadkością w muzeach europejskich na północ od Alp. Niestety zabytki te są pozbawione jakichkolwiek informacji o kontekście archeologicznym, w którym zostały znalezione. Dzięki przeprowadzonej kwerendzie muzealnej wiadomo, że Izabela Działyńska pozyskała tytułowe dzbany w 1895 roku od francuskiego zakonnika i archeologa ojca Alfreda Louisa Delattra ${ }^{3}$. Ojciec A. L. Delattre od 1894 roku prowadził badania archeologiczne jednej z nekropoli Kartaginy Douïmès (Delattre, 1897a, 1897b), której struktury datowane są na okres od VII do V w. p.n.e. (Freed, 2008, s. 85-86). Dzbany na podstawie cech morfologicznych można istotnie identyfikować jako fenickie ${ }^{4}$, jednak publikacje Delattra są zbyt

«curiosités artistiques» ku muzeum. Zbieractwo artystyczne Izabeli z Czartoryskich Działyńskiej w latach 1852-1899” z 1982 roku (oraz wcześniejszy artykuł jej autorstwa z 1969 roku), w której po raz pierwszy poza katalogiem Froehner'a (1899) oraz pierwszym polskim tomem „Corpus Vasorum Antiquorum” (1931) mówi się o zabytkach z Kartaginy w kolekcji. T. Jakimowicz porusza problematykę kolekcji również w artykule „W kręgu zbiorów gołuchowskich” z 1981 roku. Pod względem studiów nad procesem formowania się kolekcji cenne jest również opracowanie biografii Jana Działyńskiego, gdzie przedstawiono jego zainteresowania zabytkami starożytnymi i pobyt we Włoszech (Mężyński, 1987, s. 149-156 oraz wcześniejszy artykuł z 1982 roku). Zbiory gołuchowskie zostały omówione także przez wieloletniego kuratora Galerii Sztuki Starożytnej MNP Jana Szymkiewicza (1997). Całościowe ujęcie kolekcji, procesu jej formowania oraz znaczenia zbioru dla odbiorcy prezentuje książka pod redakcją D. Wysockiej (2004). Warte uwagi jest również opracowanie D. Marek dotyczące samej ordynacji gołuchowskiej (1994). Nowsze publikacje dotyczące zborów gołuchowskich traktują o powojennych losach zbiorów oraz problemie rozproszenia kolekcji (Dobrowolski, 2000; Mizera, 2000; Woźniak-Wieczorek, 2015, s. 249-262).

${ }^{2}$ Dotychczasowe publikacje dotyczące niniejszych dzbanów ograniczały się do wzmianek o pozyskaniu zabytków z Kartaginy przez właścicielkę Gołuchowa (Jakimowicz, 1982, s. 37) lub podstawowych informacji zamieszczonych w katalogach dziewiętnastowiecznych (Froehner, 1899, s. 223-225) lub dwudziestowiecznych (Pajzderski, 1929). Pierwsze naukowe opracowanie zabytków zostało zaprezentowane przez Kazimierza Bulasa w 1931 roku w pierwszym tomie Corpus Vasorum Antiquorum (Pologne 1, Gołuchów, Musée Czartoryski, pl. 54, 1, 3).

${ }^{3}$ Zachowały się dwa listy A. L. Delattra dotyczące przekazania zabytków z Kartaginy (archiwum MNPA-2794).

${ }^{4}$ Problem przynależności kulturowej do kręgu cywilizacji fenickiej lub punickiej był tematem licznych prac naukowych od lat 60. XX wieku (np. Moscati, 1963, 1993; Sznycer, 1978). Obecnie uważa się, 
ogólne, by bez cienia wątpliwości powiązać je ze stanowiskiem archeologicznym Douïmès.

Tytułowe dzbany to jedyne zabytki tego typu w Polsce. Ich wartość jest unikalna, a potencjał współczesnych metod badawczych pozwala na uzyskanie nowych informacji dotyczących ich technologii wykonania. Poznanie składu chemicznego oraz analiza petrograficzna umożliwia włączenie uzyskanych informacji do powstającej bazy danych ceramicznych zabytków fenickich.

\section{OPIS ARTEFAKTÓW}

Artefakty należą do typowego fenickiego zestawu naczyń ceramicznych. Jeden dzban posiada trójlistny wylew (nr inw. MNP A 709), natomiast drugi zaopatrzony jest w wylew grzybkowaty (nr inw. MNP A 708). Są to powszechnie znane formy przede wszystkim z kontekstów grobowych.

Zabytek z trójlistnym wylewem charakteryzuje się następującymi wymiarami: 16,2 cm (wysokość), 2,8 cm (średnica szyjki), 10,2 cm (maksymalna średnica brzuśca) 3,4 cm (średnica stopki). Jego stan można określić jako dobry: zachowana jest pełna forma, a niewielkie ubytki są obserwowalne w górnej części dzbana. Wyraźne ślady toczenia wskazują, że naczynie wykonano przy użyciu szybkoobrotowego koła garncarskiego. Glina jest jasnopomarańczowa z czerwonawymi przebarwieniami na brzuścu i uchu. Powierzchnia artefaktu jest lekko chropowata $\mathrm{z}$ widocznymi elementami drobno- i średnioziarnistej domieszki.

Płaskie dno naczynia przez ostatnie dziesięciolecia pokryte zostało numerami inwentarzowymi. Dolna część brzuśca stopniowo rozszerza się, osiągając maksymalną szerokość w jednej trzeciej wysokości całego naczynia. Załamanie w górnej części brzuśca jest bardzo charakterystyczne i świadczy o sklejeniu naczynia z dwóch części przed wypałem. Załamanie nie jest idealnie równe. Dzbany o takiej formie brzuśca w literaturze przedmiotu określa się jako kulisto-jajowate (Taloni, 2016). Dzban został zaopatrzony w wydatne ucho spełniające funkcję utylitarną, a nie tylko dekoracyjną. Trójlistny wylew jest typowy w tego rodzaju formach. Naczynie charakteryzuje się smukłym, proporcjonalnym kształtem, ale jednocześnie należy przyznać, że nie zostało wykonane ze specjalną dbałością o szczegóły.

Dzbany z trójlistnym wylewem są dobrze udokumentowane zarówno na terytorium starożytnej Fenicji, gdzie zostały odkryte na co najmniej dwunastu stanowiskach w Libanie i Izraelu (Nuñez, 2008, s. 185-186), a także na Cyprze, w basenie Morza Egejskiego, na Malcie, Sycylii, Sardynii, Ibizie, na Półwyspie Apenińskim, w Afryce

że termin ,punicki” odnosi się do Fenicjan z zachodniej części basenu Morza Śródziemnego od początków uzyskania przez Kartaginę dominującej pozycji w tej części świata, tj. od II połowy VI wieku p.n.e. (Bondí, 2014, s. 59). 
północnej oraz na Półwyspie Iberyjskim. Bezpośrednie analogie można znaleźć wśród materiału ceramicznego z następujących stanowisk: Mozia (Tusa, 1978, s. 68-70; Nigro, 2010, 2013), Laurita (Pellicer, 2007, s. 114), Trayamar (Niemeyer, Schubart, 1975; Tafel 13, s. 552) i Kartagina (Cintas, 1970, pl. XXI; Cintas, 1976, 287, pl. XCIV). Na podstawie kulisto-jajowatego kształtu brzuśca oraz licznych analogii z basenu Morza Śródziemnego naczynie można datować na pierwszą połowę VII w. p.n.e.

Dzban w grzybkowatym wylewem jest nieco mniejszy od naczynia opisywanego wcześniej: $14 \mathrm{~cm}$ (wysokość), 5,5 cm (średnica wylewu), $9 \mathrm{~cm}$ (maksymalna średnica brzuśca) 4,4 cm (średnica stopki). Jego stan zachowania jest również dobry; niewielkie wyszczerbienie posiada jedynie krawędź wylewu. Podobnie jak naczynia z trójlistnym wylewem, dzban wykonany został na kole szybkoobrotowym ${ }^{5}$. Charakteryzuje się płaskim dnem, wydatnym brzuścem, prostą szyjką oraz grzybkowatym wylewem. Niewielkie ucho opiera się na górnej części brzuśca i dochodzi do szyjki. Kolor naczynia jest jednorodny, ceglastoczerwony, jednak miejscami widoczne są przebarwienia. Jego powierzchnia jest lekko chropowata, widać na niej drobnoziarnistą domieszkę. Ze względu na charakterystyczny, kulisty brzusiec oraz brak czerwonej polewy (Maass-Lindemann 2006, s. 294), artefakt datować można na VII wiek p.n.e., ze wskazaniem na pierwszą połowę (por. Peserico, 1996, tab. 7).

Zasięg występowania dzbanów z grzybkowanym wylewem jest taki sam jak wcześniej opisywanej formy; naczynia z trójlistnym oraz grzybkowatym wylewem zazwyczaj występują razem. Dzbany pełniły funkcje rytualne związane $\mathrm{z}$ obrządkiem pogrzebowym, na co wskazuje kontekst znalezisk (Aubet, 2010, s. 154). Naczynia te pełniły funkcję przystawek. Zdaniem A. Neville naczynia z trójlistnym wylewem zawierały wodę lub wino, natomiast te $\mathrm{z}$ grzybkowatym wylewem oliwę lub balsam (Neville, 2008, s. 49).

\section{METODA}

Podstawową metoda badawczą, dzięki której rozpoznano skład chemiczny artefaktów, była spektrometria fluorescencji rentgenowskiej (XRF). Dzbany badano przy użyciu ręcznego spektrometru Bruker Tracer III SD. Aparatura tego typu w ostatnich latach pozwoliła na przeprowadzenie badań artefaktów o wysokiej wartości artystycznej, których nie można było poddać próbkowaniu. Zalety spektrometru są bezdyskusyjne; pozwala on uzyskać skład pierwiastkowy powierzchni artefaktu, nie powodując jakiegokolwiek naruszenia substancji zabytkowej ${ }^{6}$. W przypadku wyjątkowych zabytków, do jakich należą tytułowe dzbany, jest to jedna z niewielu

\footnotetext{
${ }^{5}$ Proces toczenia dzbanów tego typu został przedstawiony w artykule W. P. Andersona z 1990 r.

${ }^{6}$ Opis działania spektrometru wraz z wyszczególnieniem jego zalet $\mathrm{i}$ wad był przedmiotem wielu publikacji w ostatnich latach, zob. szczególnie Ownby, 2012, Shackley, 2011, Shugar, Mass, 2012.
} 


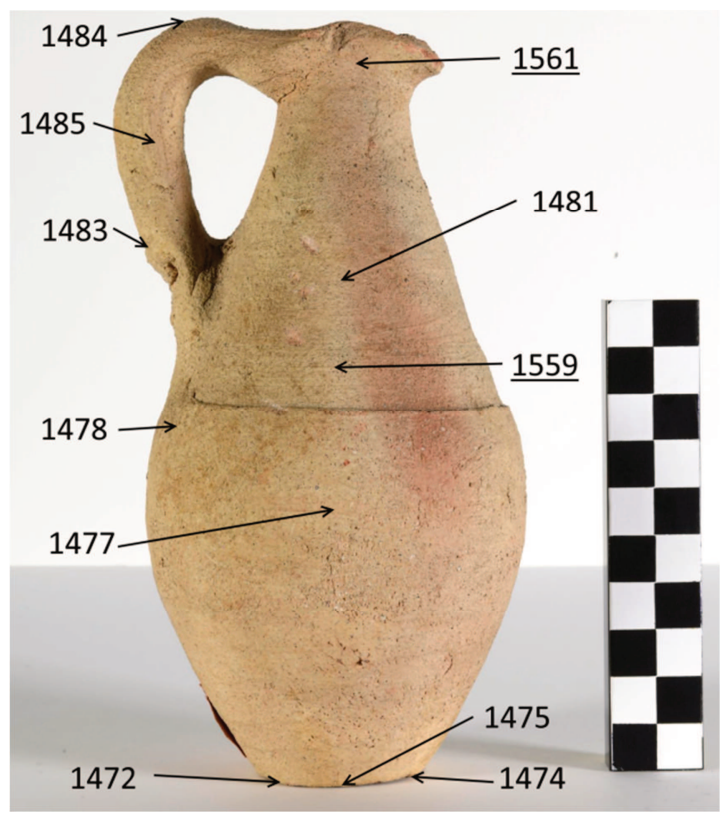

Ryc. 1. Numery pomiarów zaznaczone na tle dzbana z trójlistnym wylewem - strona A

Fig. 1. The numbers of measurements marked on the background of the jug with trefoil lip - surface A

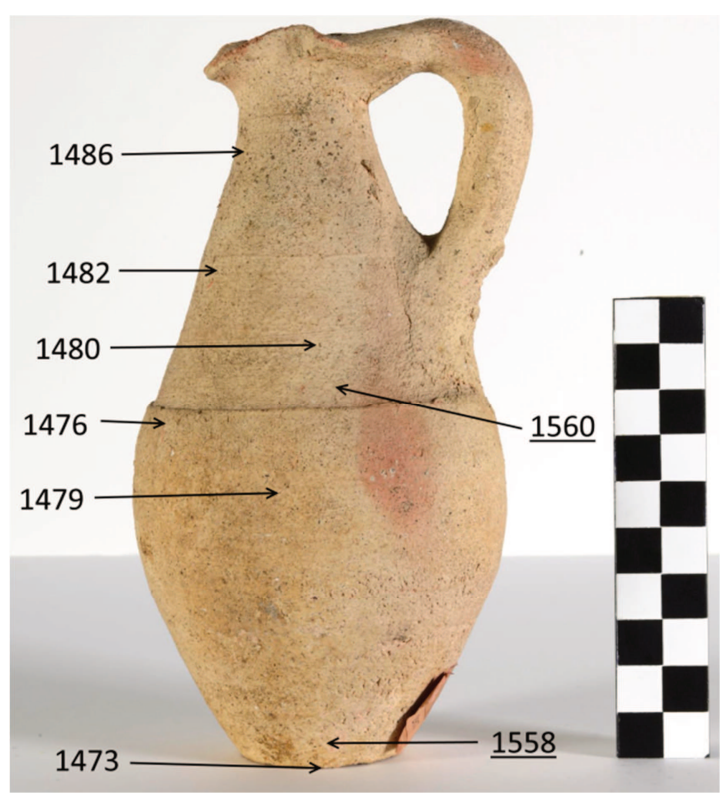

Ryc. 2. Numery pomiarów zaznaczone na tle dzbana z trólistnym wylewem - strona B

Fig. 2. The numbers of measurements marked on the background of the jug with trefoil lip - surface B 


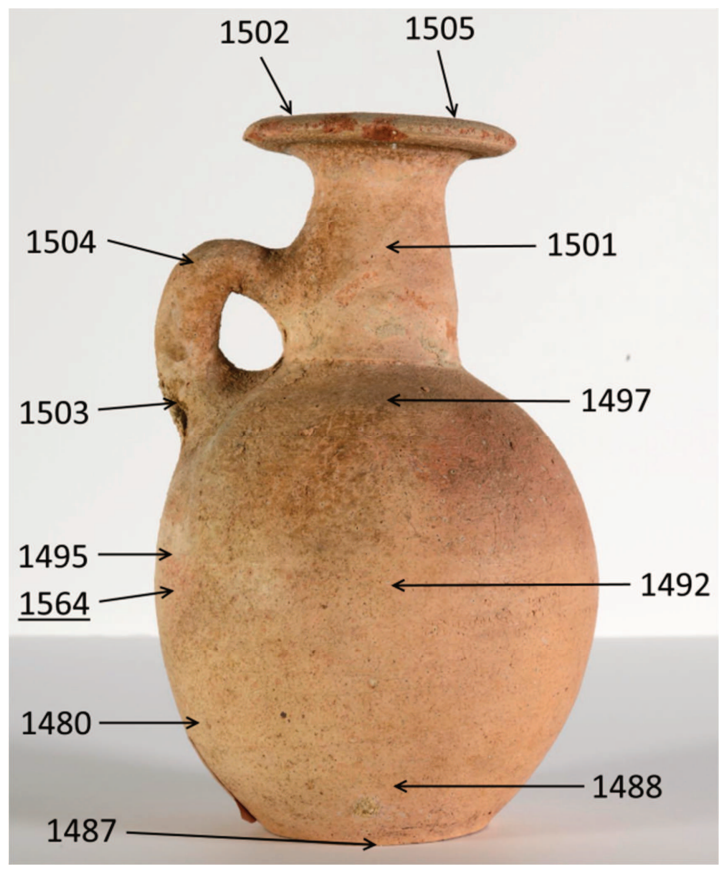

Ryc. 3. Numery pomiarów zaznaczone na tle dzbana z grzybkowatym wylewem - strona A

Fig. 3. The numbers of measurements marked on the background of the mushroom-lipped jug - surface A

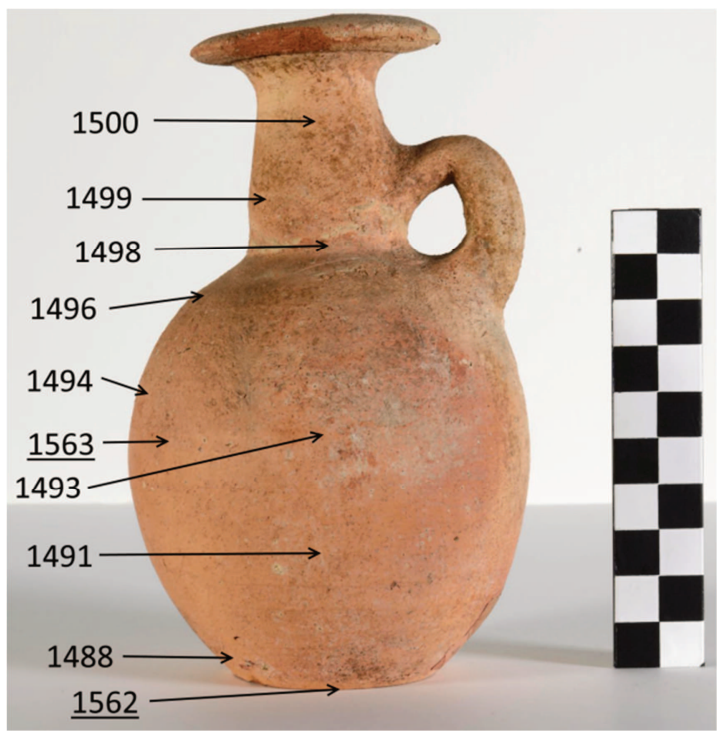

Ryc. 4. Numery pomiarów zaznaczone na tle dzbana z grzybkowatym wylewem - strona B

Fig. 4. The numbers of measurements marked on the background of the mushroom-lipped jug - surface B 
metod umożliwiająca poznanie szczegółów technologicznych badanych artefaktów. Należy przy tym podkreślić, że uzyskany skład chemiczny dotyczy wyłącznie powierzchni i nie jest reprezentatywny dla całego zabytku. Tym niemniej, biorąc pod uwagę ograniczenia konserwatorskie, w obecnych warunkach jest to jedyny sposób pozwalający na poznanie powierzchniowego składu chemicznego zabytków.

Dzbany badano przy użyciu dwóch odrębnych trybów analitycznych dostarczonych przez producenta aparatury: Major Mud Rock oraz Trace Mud Rock. Pozwalają one na automatyczny wybór paramentów odpowiednich dla próbek geologicznych, w tym ceramiki. W przypadku Major Mud Rock, czyli w trybie ogólnym, napięcie wynosiło $15 \mathrm{kV}$, natężenie $25 \mu \mathrm{A}$, czas jednego pomiaru był równy 15 sekundom, nie stosowano filtrów, użyto natomiast pompy próżniowej. Tryb Trace Mud Rock charakteryzował się następującymi parametrami: napięcie $40 \mathrm{kV}$, natężenie $15 \mu \mathrm{A}$, czas pomiaru równy 120 sekundom, żółty filtr, brak pompy próżniowej. Wykonano 15 pomiarów w trybie Major Mud Rock dzbana z trójlistnym wylewem oraz 19 pomiarów dzbana z grzybkowatym wylewem, ryciny $1-4$ obrazują miejsca poddane analizom. W trybie Trace Mud Rock przeprowadzono cztery pomiary dzbana $\mathrm{z}$ trójlistnym wylewem oraz trzy - dzbana z grzybkowatym wylewem ${ }^{7}$. Za każdym razem spektrometr ściśle przylegał do powierzchni naczyń, a więc odległość między detektorem a analizowanym miejscem artefaktu była zawsze taka sama.

Analiza mikroskopowa stanowiła metodę komplementarną. Użyto mikroskopu optycznego i analizowano tylko miejsca z odpryskami, które umożliwiały obserwację dodanych domieszek. Rzecz jasna ze względów konserwatorskich nie istniała możliwość pobrania próbki czy oszlifowania fragmentu powierzchni dzbanów. $\mathrm{Z}$ tego powodu wyniki obserwacji mikroskopowej należy traktować nie jako analizę petrograficzną sensu stricto, lecz jako uzupełnienie ogólnej charakterystyki technologicznej badanych artefaktów.

\section{WYNIKI}

Dzięki przeprowadzonym pomiarom uzyskano rezultaty dla 14 pierwiastków w trybie Major Mud Rock oraz dla 22 pierwiastków (w tym dla dwóch częściowo) w trybie Trace Mud Rock. Wyniki w postaci wartości numerycznych prezentuje tabela 1 i 2 . Miara zmienności wyników chemicznych jest niewielka, odchylenia standardowe są największe dla krzemu oraz wapnia, co jest typowym zjawiskiem dla przedmiotów ceramicznych. Niskie wartości odchyleń standardowych wskazują na homogeniczność badanych artefaktów.

Ze względu na wpływ procesów podepozycyjnych oraz innych czynników porównanie wyników chemicznych między odrębnymi artefaktami należy przeprowadzić na podstawie ograniczonego zestawu pierwiastków (Goren i in., 2011, s. 689).

\footnotetext{
${ }^{7}$ Na rycinach 1-4 analizy w trybie Trace Mud Rock oznaczono podkreśleniem.
} 
Tabela 1. Wyniki składu pierwiast

Table 1. Elemental composition

\begin{tabular}{|c|c|c|c|c|c|c|c|}
\hline POMIAR & $\mathrm{Na}$ & $\mathrm{Mg}$ & $\mathrm{Al}$ & $\mathrm{Si}$ & S & K & $\mathrm{Ca}$ \\
\hline 1472 & 0,37 & 2,5699 & 1,5374 & 5,8043 & 0,1015 & 0,2553 & 3,4208 \\
\hline 1473 & 0,4588 & 2,2045 & 1,5447 & 5,9809 & 0,8118 & 0,2515 & 3,2092 \\
\hline 1474 & 0,525 & 1,5858 & 2,3411 & 6,4124 & 2,026 & 0,3879 & 4,4243 \\
\hline 1475 & 0,438 & 2,2856 & 1,832 & 6,138 & 1,8629 & 0,3969 & 3,5512 \\
\hline 1476 & 0,5021 & 1,5803 & 1,7059 & 5,9485 & 1,6017 & 0,3431 & 4,235 \\
\hline 1477 & 0,4723 & 1,8646 & 1,5832 & 6,0994 & 2,0356 & 0,4717 & 3,4664 \\
\hline 1478 & 0,4811 & 2,127 & 1,8999 & 6,5524 & 1,2042 & 0,4193 & 4,3309 \\
\hline 1479 & 0,5001 & 1,5632 & 1,5124 & 5,989 & 1,372 & 0,4042 & 4,2643 \\
\hline 1480 & 0,4413 & 1,887 & 1,7478 & 6,242 & 0,6098 & 0,2494 & 4,5789 \\
\hline 1481 & 0,435 & 2,1303 & 1,1405 & 4,8503 & 0,8621 & 0,2928 & 3,6756 \\
\hline 1482 & 0,3371 & 2,7484 & 1,0177 & 4,0497 & 0,563 & 0,1502 & 3,2509 \\
\hline 1483 & 0,4242 & 2,0852 & 1,4721 & 5,6392 & 0,8227 & 0,2595 & 4,0451 \\
\hline 1484 & 0,4292 & 2,0163 & 1,7047 & 6,9504 & 1,274 & 0,2938 & 3,1041 \\
\hline 1485 & 0,4332 & 1,8322 & 1,3493 & 5,3244 & 1,2685 & 0,4044 & 3,4153 \\
\hline 1486 & 0,3929 & 2,2245 & 1,1434 & 4,5242 & 0,5915 & 0,2241 & 3,6635 \\
\hline średnia & 0,44268667 & 2,04698667 & 1,56880667 & 5,76700667 & 1,13382 & 0,32027333 & 3,7757 \\
\hline $\begin{array}{l}\text { odchylenie } \\
\text { standardowe }\end{array}$ & 0,05058311 & 0,34475198 & 0,33543772 & 0,78299763 & 0,57901925 & 0,09068035 & 0,4904971 \\
\hline 1487 & 0,3426 & 2,3975 & 1,151 & 5,4976 & 0,1474 & 0,5256 & 3,639 \\
\hline 1488 & 0,4637 & 1,8092 & 1,6771 & 5,7879 & 1,053 & 0,6656 & 4,1842 \\
\hline 1489 & 0,4882 & 1,6017 & 1,8995 & 6,5195 & 1,0469 & 0,7068 & 3,8701 \\
\hline 1490 & 0,3608 & 2,457 & 1,7404 & 6,2759 & 0,8933 & 0,6783 & 3,8108 \\
\hline 1491 & 0,4486 & 1,9349 & 2,0188 & 6,5619 & 0,9195 & 0,8989 & 4,1093 \\
\hline 1492 & 0,4883 & 1,8343 & 1,6553 & 6,3809 & 1,2695 & 0,6564 & 4,1291 \\
\hline 1493 & 0,4313 & 2,2459 & 1,6041 & 6,1483 & 0,8534 & 0,6915 & 5,2621 \\
\hline 1494 & 0,4437 & 1,8386 & 2,0598 & 7,6237 & 0,9572 & 0,8524 & 3,6759 \\
\hline 1495 & 0,5007 & 1,6934 & 1,6102 & 5,8895 & 1,1834 & 0,6099 & 4,8184 \\
\hline 1496 & 0,4699 & 1,98 & 1,7698 & 6,5033 & 1,0735 & 0,8141 & 3,9215 \\
\hline 1497 & 0,4837 & 1,6968 & 1,5327 & 5,4437 & 1,5117 & 0,62 & 4,0989 \\
\hline 1498 & 0,4563 & 2,0558 & 1,2381 & 5,2964 & 0,9224 & 0,6264 & 3,9091 \\
\hline 1499 & 0,5297 & 1,4375 & 1,7121 & 6,1584 & 1,155 & 0,6705 & 4,933 \\
\hline 1500 & 0,4703 & 1,8976 & 1,3311 & 5,0184 & 1,1606 & 0,6767 & 4,0849 \\
\hline 1501 & 0,4746 & 1,9972 & 1,2226 & 5,0557 & 0,7382 & 0,4579 & 3,8124 \\
\hline 1502 & 0,426 & 2,2561 & 1,1934 & 5,2023 & 0,6863 & 0,5624 & 3,2388 \\
\hline 1503 & 0,4788 & 2,1942 & 0,6547 & 3,5428 & 0,8446 & 0,3063 & 6,6657 \\
\hline 1504 & 0,3998 & 2,3799 & 1,0404 & 4,3718 & 0,7999 & 0,5108 & 3,0236 \\
\hline 1505 & 0,4511 & 2,0565 & 1,7448 & 5,7036 & 0,8699 & 0,7617 & 3,6194 \\
\hline średnia & 0,45305789 & 1,98758421 & 1,51873158 & 5,73587368 & 0,95187895 & 0,64695789 & 4,14769474 \\
\hline $\begin{array}{l}\text { odchylenie } \\
\text { standardowe }\end{array}$ & 0,04610182 & 0,28326956 & 0,36256278 & 0,90678104 & 0,27953662 & 0,13943069 & 0,81375268 \\
\hline
\end{tabular}


kowego w trybie Major Mud Rock

results in Major Mud Rock mode

\begin{tabular}{|c|c|c|c|c|c|c|}
\hline $\mathrm{Ti}$ & $\mathrm{Mn}$ & $\mathrm{Fe}$ & Co & $\mathrm{Cu}$ & $\mathrm{Zn}$ & $\mathrm{Ba}$ \\
\hline 0,8765 & 0,0133 & 2,0714 & 0,0007 & 0,0058 & 0,0098 & 0,1095 \\
\hline 0,8852 & 0,0086 & 2,2388 & 0,0008 & 0,0061 & 0,009 & 0,1994 \\
\hline 0,8689 & 0,0142 & 2,2129 & 0,0008 & 0,0057 & 0,012 & 0,1804 \\
\hline 0,8652 & 0,0107 & 2,311 & 0,0008 & 0,0041 & 0,01 & 0,2167 \\
\hline 0,8516 & 0,0132 & 1,9718 & 0,0007 & 0,0065 & 0,0122 & 0,2432 \\
\hline 0,8662 & 0,0097 & 2,2476 & 0,0008 & 0,0053 & 0,0106 & 0,1942 \\
\hline 0,8788 & 0,0138 & 2,0111 & 0,0007 & 0,0074 & 0,0131 & 0,1054 \\
\hline 0,8271 & 0,0171 & 1,9715 & 0,0006 & 0,0064 & 0,0128 & 0,2248 \\
\hline 0,8712 & 0,0121 & 1,9992 & 0,0007 & 0,0081 & 0,0149 & 0,0978 \\
\hline 0,814 & 0,0114 & 2,033 & 0,0007 & 0,0073 & 0,0146 & 0,1902 \\
\hline 0,8096 & 0,0107 & 1,8495 & 0,0005 & 0,0064 & 0,0127 & 0,1261 \\
\hline 0,8376 & 0,0132 & 1,8196 & 0,0006 & 0,0084 & 0,0164 & 0,1598 \\
\hline 0,862 & 0,0099 & 2,1966 & 0,0008 & 0,0058 & 0,0099 & 0,2086 \\
\hline 0,8296 & 0,0098 & 2,0426 & 0,0007 & 0,0065 & 0,0131 & 0,1416 \\
\hline 0,8298 & 0,0201 & 1,914 & 0,0006 & 0,0062 & 0,0131 & 0,1894 \\
\hline 0,85155333 & 0,01252 & 2,05937333 & 0,0007 & 0,0064 & 0,01228 & 0,17247333 \\
\hline 0,02480172 & 0,003048 & 0,15082529 & $9,2582 \mathrm{E}-05$ & 0,00108759 & 0,00211059 & 0,04641966 \\
\hline 0,8508 & 0,0134 & 1,9271 & 0,0006 & 0,0051 & 0,0107 & 0,2163 \\
\hline 0,8389 & 0,0159 & 1,9507 & 0,0007 & 0,0052 & 0,0096 & 0,168 \\
\hline 0,8751 & 0,0268 & 2,0208 & 0,0007 & 0,0049 & 0,0088 & 0,1365 \\
\hline 0,8307 & 0,0126 & 2,0016 & 0,0006 & 0,0177 & 0,0388 & 0,1033 \\
\hline 0,8323 & 0,0116 & 2,0823 & 0,0007 & 0,0049 & 0,0099 & 0,1849 \\
\hline 0,8396 & 0,0167 & 2,0694 & 0,0007 & 0,0059 & 0,0107 & 0,1738 \\
\hline 0,8541 & 0,0136 & 2,0071 & 0,0007 & 0,008 & 0,0149 & 0,2069 \\
\hline 0,8592 & 0,0107 & 2,1216 & 0,0007 & 0,0049 & 0,0099 & 0,1766 \\
\hline 0,8308 & 0,0147 & 2,0357 & 0,0007 & 0,0151 & 0,0327 & 0,2044 \\
\hline 0,85 & 0,0135 & 2,0134 & 0,0007 & 0,0047 & 0,0096 & 0,1477 \\
\hline 0,8771 & 0,0144 & 2,0958 & 0,0007 & 0,0059 & 0,0101 & 0,1111 \\
\hline 0,8212 & 0,0142 & 2,0503 & 0,0007 & 0,0055 & 0,0103 & 0,1101 \\
\hline 0,8762 & 0,0124 & 2,1635 & 0,0007 & 0,0041 & 0,0099 & 0,2042 \\
\hline 0,8343 & 0,0186 & 2,0554 & 0,0007 & 0,0057 & 0,0091 & 0,143 \\
\hline 0,8688 & 0,0102 & 2,0901 & 0,0007 & 0,006 & 0,0101 & 0,1506 \\
\hline 0,8593 & 0,0111 & 2,1262 & 0,0007 & 0,0058 & 0,0099 & 0,122 \\
\hline 0,7972 & 0,0133 & 1,5235 & 0,0004 & 0,0046 & 0,0108 & 0,2682 \\
\hline 0,8245 & 0,0125 & 1,9794 & 0,0006 & 0,0053 & 0,0106 & 0,1513 \\
\hline 0,8543 & 0,0105 & 2,0588 & 0,0007 & 0,0066 & 0,0103 & 0,1578 \\
\hline 0,84602105 & 0,01403684 & 2,01961579 & 0,00066842 & 0,00662632 & 0,01298421 & 0,16508947 \\
\hline 0,02122678 & 0,00377377 & 0,13442007 & 7,4927E-05 & 0,00357333 & 0,00817967 & 0,04240082 \\
\hline
\end{tabular}


Tabela 2. Wyniki składu pierwiast

Table 2. Elemental composition

\begin{tabular}{|c|l|l|l|l|l|l|l|l|l|l|l|l|}
\hline POMIAR & \multicolumn{1}{|c|}{$\mathrm{Ca}$} & \multicolumn{1}{|c|}{$\mathrm{Ti}$} & $\mathrm{Cr}$ & $\mathrm{Mn}$ & $\mathrm{Fe}$ & $\mathrm{Co}$ & $\mathrm{Ni}$ & $\mathrm{Cu}$ & $\mathrm{Zn}$ & $\mathrm{As}$ & $\mathrm{Rb}$ \\
\hline 1558 & 11,028 & 0,5131 & & 0,0445 & 3,0024 & 0,0013 & 0,0032 & 0,013 & 0,0158 & 0,001 & 0,0024 \\
\hline 1559 & 9,7956 & 0,5555 & 0,0001 & 0,0298 & 2,9693 & 0,0014 & 0,0027 & 0,0117 & 0,0143 & 0,001 & 0,0021 \\
\hline 1560 & 13,0322 & 0,508 & & 0,0513 & 2,9774 & 0,0015 & 0,0034 & 0,0116 & 0,0161 & 0,0012 & 0,004 \\
\hline 1561 & 9,545 & 0,5518 & 0,0024 & 0,0363 & 3,3979 & 0,0016 & 0,0031 & 0,0119 & 0,0171 & 0,0149 & 0,0014 \\
\hline średnia & 10,8502 & 0,5321 & 0,00125 & 0,040475 & 3,08675 & 0,00145 & 0,0031 & 0,01205 & 0,015825 & 0,004525 & 0,002475 \\
\hline $\begin{array}{l}\text { odchylenie } \\
\text { standardowe }\end{array}$ & 1,59253101 & 0,02501639 & 0,00162635 & 0,00939446 & 0,20791117 & 0,0001291 & 0,00029439 & 0,0006455 & 0,00115866 & 0,00691731 & 0,00109962 \\
\hline 1562 & 9,3645 & 0,5002 & & 0,0386 & 2,9371 & 0,0014 & 0,0029 & 0,0093 & 0,0122 & 0,0014 & 0,0042 \\
\hline 1563 & 9,9222 & 0,4937 & & 0,0488 & 2,7461 & 0,0015 & 0,0038 & 0,0105 & 0,0151 & 0,0017 & 0,004 \\
\hline 1564 & 13,387 & 0,4822 & & 0,0544 & 2,8195 & 0,0015 & 0,0036 & 0,0205 & 0,088 & 0,0041 & 0,004 \\
\hline średnia & 10,8912333 & 0,49203333 & & 0,04726667 & 2,83423333 & 0,00146667 & 0,00343333 & 0,01343333 & 0,03843333 & 0,0024 & 0,00406667 \\
\hline $\begin{array}{l}\text { odchylenie } \\
\text { standardowe }\end{array}$ & 2,17931085 & 0,00911501 & & 0,00801083 & 0,0963486 & $5,7735 \mathrm{E}-05$ & 0,00047258 & 0,00614925 & 0,04295048 & 0,00147986 & 0,00011547 \\
\hline
\end{tabular}

Wcześniejsze badania pokazują, że w przypadku trybu Major Mud Rock najbardziej wiarygodny zbiór to $\mathrm{Al}, \mathrm{Si}, \mathrm{K}, \mathrm{Ca}, \mathrm{Ti}, \mathrm{V}, \mathrm{Cr}, \mathrm{Fe}$ (Krueger, Brandherm, w druku). Zawartość procentowa pierwiastków w przypadku obu dzbanów jest bardzo podobna, jedynie w przypadku potasu różnice mogą być znaczące; dla dzbana z trójlistnym wylewem średnia wartość wynosi $0,32 \%$, a dla dzbana z grzybkowatym wylewem $0,64 \%$. Na tym etapie badań, przy braku komparatystycznych informacji o innych artefaktach fenickich z Kartaginy ${ }^{8}$, trudno oszacować wagę tych wartości dla zrozumienia odmienności wyników dla potasu. Będzie to możliwe dopiero po uzupełnieniu bazy danych o nowe artefakty i przeprowadzeniu podstawowych testów statystycznych, takich jak na przykład test potasu-tytanu czy analiza głównych składowych. Ważne jest przy tym użycie tej samej aparatury oraz metodyki analiz. Rozbieżności w zakresie metodyki prowadzą do uzyskiwania izolowanych rezultatów, których nie da się porównać pod względem ilościowym, a jedynie jakościowym. Obecnie analiza wyników na podstawie wyszczególnionych pierwiastków pozwala na wyciągniecie wniosku o chemicznej homogeniczności badanych zabytków. Potwierdzeniem tego stanu rzeczy jest obecność uranu, rzadkiego pierwiastka w naczyniach ceramicznych, który został zidentyfikowany w obu dzbanach. Pierwiastek ten może $\mathrm{w}$ przyszłości pomóc $\mathrm{w}$ identyfikacji pokładów gliny, $\mathrm{z}$ którego czerpano surowiec do wyrobu naczyń. Na razie brakuje jednak bazy wyników chemicznych dla gliny eksploatowanej w Kartaginie i jej okolicach. Powyższe rezultaty oznaczają, że każdy z artefaktów został wykonany z jednolitej pod względem chemicznym wyszlamowanej masy ceramicznej. Jedyne obserwowalne odchylenie dotyczy pomiaru 1503, jednak jest ono spowodowane wpływem widocznej na zdjęciu konkrecji, a nie zmiennością samej masy ceramicznej.

\footnotetext{
${ }^{8}$ Wyjątkiem jest artykuł M. L. Amadori i B. Fabbri z 1998 roku oraz M. L. Amadori i in. z 2017 roku, jednak w obu przypadkach różnice w zakresie użytej aparatury oraz metodyki nie pozwalają na bezpośrednie porównanie danych.
} 
kowego w trybie Trace Mud Rock

results in Trace Mud Rock mode

\begin{tabular}{|c|c|c|c|c|c|c|c|c|c|c|c|}
\hline $\mathrm{Sr}$ & $\mathrm{Y}$ & $\mathrm{Zr}$ & $\mathrm{Nb}$ & Mo & $\mathrm{Sn}$ & $\mathrm{Sb}$ & $\mathrm{Ba}$ & $\mathrm{Pb}$ & $\mathrm{Pb}$ Err & $\mathrm{Th}$ & $\mathrm{U}$ \\
\hline 0,033 & 0,0023 & 0,0098 & 0,0004 & 0,0026 & 0,0003 & 0,0017 & 0,3031 & 0,0012 & 0,0001 & 0,0004 & \\
\hline 0,0295 & 0,0022 & 0,0122 & 0,0004 & 0,0028 & 0,0003 & 0,0013 & 0,0575 & 0,0012 & 0,0001 & 0,0004 & \\
\hline 0,042 & 0,0021 & 0,0117 & 0,0005 & 0,0012 & 0,0003 & 0,0011 & 0,2566 & 0,0013 & 0,0001 & 0,0005 & 0,0002 \\
\hline 0,0358 & 0,0031 & 0,0126 & 0,0005 & 0,0004 & 0,0002 & 0,0007 & 0,2082 & 0,0035 & 0,0001 & 0,0006 & \\
\hline 0,035075 & 0,002425 & 0,011575 & 0,00045 & 0,00175 & 0,000275 & 0,0012 & 0,20635 & 0,0018 & 0,0001 & 0,000475 & 0,0002 \\
\hline 0,00528733 & 0,00045735 & 0,00123929 & $5,7735 \mathrm{E}-05$ & 0,00114746 & 0,00005 & 0,00041633 & 0,10652914 & 0,00113431 & 0 & $9,5743 \mathrm{E}-05$ & \\
\hline 0,0254 & 0,0024 & 0,0109 & 0,0005 & 0,002 & 0,0003 & 0,0013 & 0,1703 & 0,0016 & 0,0001 & 0,0005 & \\
\hline 0,0273 & 0,0023 & 0,0109 & 0,0005 & 0,0015 & 0,0002 & 0,001 & 0,1324 & 0,0017 & 0,0001 & 0,0005 & \\
\hline 0,0346 & 0,0023 & 0,013 & 0,0005 & 0,0004 & 0,0002 & 0,0008 & 0,2132 & 0,0014 & 0,0001 & 0,0005 & 0,0003 \\
\hline 0,0291 & 0,00233333 & 0,0116 & 0,0005 & 0,0013 & 0,00023333 & 0,00103333 & 0,17196667 & 0,00156667 & 0,0001 & 0,0005 & 0,0003 \\
\hline 0,00485695 & $5,7735 \mathrm{E}-05$ & 0,00121244 & 0 & 0,00081854 & $5,7735 \mathrm{E}-05$ & 0,00025166 & 0,04042578 & 0,00015275 & 0 & 0 & \\
\hline
\end{tabular}

W przypadku dzbana z grzybkowatym wylewem jako domieszki użyto kwarcu transparentnego, rzadziej mlecznego oraz skaleni (ortoklazów). W masie ceramicznej sporadycznie pojawiają się wapienie, a także kalcyt. Jest prawdopodobne, że w masie znajdują się amfibole i pirokseny, jednak tę hipotezę należy zweryfikować przy użyciu bardziej dokładnych metod petrograficznych. Zastosowano domieszkę piaskową, na co wskazuje okrągły lub zbliżony do owalu kształt ziaren.

Powierzchowna obserwacja masy ceramicznej naczynia z trójlistnym wylewem wskazuje na glinę wapienną, marglową, jednak wyniki chemiczne nie wykazują znaczących różnic w stężeniu wapnia w obu naczyniach. Domieszka składa się z ziaren wapieni i kalcytów, okazjonalnie występują kwarce, skalenie (ortoklazy), natomiast rzadko tlenki żelaza. Prawdopodobnie w masie ceramicznej znajduje się także biotyt, ale to stwierdzenie wymaga weryfikacji. Wykonanie płytek cienkich (por. Dubińska, Bagiński, 1995) dla obu naczyń pozwoliłoby na precyzyjną identyfikację zastosowanych domieszek.

\section{PODSUMOWANIE}

Dzbany z Gołuchowa posiadają wyjątkowy dla polskiego muzealnictwa archeologicznego charakter. Zabytki z kręgu cywilizacji fenickiej i punickiej są w naszym kraju niezwykle rzadkie i zwykle datowane są na okres późny. Dwa dzbany z kolekcji gołuchowskiej można natomiast łączyć z obecnością Fenicjan na terenie centralnego basenu Morza Śródziemnego; kontekst uzyskania dzbanów przez Izabelę Działyńską wskazuje na Kartaginę jako ośrodek produkcji. Ta teza znajduje potwierdzenie również w cechach morfologicznych naczyń, typowych dla wieku VII p.n.e. Był to czas, kiedy Kartagina dopiero zaczynała wybijać się na niepodległość, prowadząc niezależną od Tyru akcję kolonizacyjną zachodniej części basenu Morza Śródziemnego (Aubet, 2001; Hours-Miédan, 1998; Markoe, 2000). 
Dzięki uzyskanym wynikom chemicznym można stwierdzić, że każde z naczyń zostało wykonane z tej samej gliny, tzn. podczas toczenia nie miało miejsca zjawisko dolepiania elementów naczynia, takich jak ucho, szyja czy wylew z odmiennej masy ceramicznej. Co więcej, skład pierwiastkowy wskazuje na wysokie podobieństwo obu naczyń pod względem chemicznym. Najprawdopodobniej były one wytaczane z tych samych pokładów gliny. Powyższe wyniki mogą stanowić źródło do badań komparatystycznych innych zabytków tego typu.

\section{PODZIĘKOWANIA}

Projekt został sfinansowany ze środków Narodowego Centrum Nauki na podstawie decyzji 2013/09/B/HS3/00630. Autorzy składają serdeczne podziękowania Dyrekcji Muzeum Narodowego w Poznaniu oraz pracownikom Muzeum Zamku w Gołuchowie za udostępnienie oraz wsparcie podczas prowadzonych analiz, p. Marcie Krueger za pomoc w interpretacji mikrofotografii badanych dzbanów oraz dwóm anonimowym recenzentom za cenne uwagi i sugestie.

\section{BIBLIOGRAFIA}

Amadori M. L., Fabbri B.

1998a Indagini archeometriche su ceramica fenicia da mensa proveniente da Cartagine (VIIIVI secolo a. C.). W: Acquaro E, Fabbri B (red.), Produzione e circolazione della ceramica fenicia e punica nel Mediterraneo: il contributo delle analisi archeometriche. Atti della 2 a Giornata di Archeometria Della Ceramica (Ravenna, 14 maggio 1998, s. 43-55). Imola: University Press Bologna.

Amadori M. L., Del Vais C., Fermo P., Pallante P.

2017 Archaeometric researches on the provenance of Mediterranean Archaic Phoenician and Punic pottery. Environmental Science and Pollution Research 24(16), s. 13 921-13949.

Anderson W. P.

1990 The Beginnings of Phoenician Pottery: Vessel Shape, Style, and Ceramic Technology in the Early Phases of the Phoenician Iron Age. Bulletin of the American Schools of Oriental Research, 279, s. 35-54.

Aubet M. E.

2001 The Phoenicians and the West: Politics, Colonies and Trade. Cambridge: Cambridge University Press.

2010 The Phoenician cemetery of Tyre. Near Eastern Archaeology, 73, s. 144-155.

Beazley J.

1928 Greek vases in Poland. Oxford: Clarendon Press.

Bondì S. F.

2014 Phoenicity, punicities. W: J. Crawley Quinn, N. C. Vella (red.), The Punic Mediterranean. Identities and Identification from Phoenician Settlement to Roman Rule (s. 58-68). Cambridge: Cambridge University Press. 
Bulas K.

1931 Corpus Vasorum Antiquorum, Pologne 1: Gołuchów, Musée Czartoryski. Varsovie Cracovie: Académie Polonaise des Sciences et des Lettres.

Cintas P.

$1970 \quad$ Manuel d'archéologie punique I. Paris: A. et J. Picard.

Cintas P.

1976 Manuel d'archéologie punique II. Paris: A. et J. Picard.

Delattre A. L.

1897a Carthage: quelques tombeaux de la nécropole punique de Doü̈mes (1892-1894). Lyon: Mougin-Rusand.

1897b La nécropole punique de Douïmès (a Carthage): fouilles de 1895 et 1896. Paris.

Dobrowolski W.

2000 Wazy gołuchowskie w Warszawie czy w Gołuchowie? W: J. Lipińska (red.), Zbiory publiczne a kolekcjonerstwo prywatne. Problematyka ochrony dziedzictwa kulturowego w przeszłości i dzisiaj, materiały sesji naukowej w Muzeum Narodowym w Warszawie zorganizowanej przez pracowników Zbiorów Sztuki Starożytnej - listopad 1998 (s. 69-76). Warszawa: Muzeum Narodowe w Warszawie.

Dubińska E., Bagiński B.

1995 Minerały skałotwórcze w ptytkach cienkich: vademecum. Warszawa: Wydział Geologii UW.

Freed J.

2008 Le père Alfred-Louis Delattre (1850-1932) et les fouilles archéologiques de Carthage. Histoire et missions chrétiennes, 8, s. 67-100.

Froehner W.

1899 Collections du Chateau de Goluchow. Antiquites. Supplement. Paris.

Goren Y., Mommsen H., Klinger J.

2011 Non-destructive provenance study of cuneiform tablets using portable X-ray fluorescence (pXRF). Journal of Archaeological Science, 38, s. 684-696.

Hours-Miédan M.

1998 Kartagina. Warszawa: Oficyna Wydawnicza Volumen.

Jakimowicz T.

1969 Izabelli z Czartoryskich Działyńskiej Paradis Terrestre. Studia Muzealna, 7, s. 55-76.

1981 W kręgu zbiorów gołuchowskich. W: J. A. Chrościcki i in. (red.), Ars auro prior. Studia Ioanni Białostocki sexagenario dicata (s. 693-697). Warszawa: PWN.

1982 Od kolekcji „curiosités artistiques” ku muzeum. Zbieractwo artystyczne Izabeli z Czartoryskich Działyńskiej w latach 1852-1899. Studia Muzealne, 13, s. 15-73.

Krueger M., Brandherm D.

W druku Chemical characterization via pXRF of Early Iron Age pottery from SW Iberia. W: red. B. Török (red.), Latest Results and Examination Methodologies of Pre- and Protohistoric Metals and Other Inorganic Materials. $I^{\text {st }}$ International Scientific Conference of the UISPP Commission on Archaeometry of Pre- and Protohistoric Inorganic Artifacts, Materials and Technologies. Miskolc: University of Miskolc.

Maass-Lindemann G.

2006 Interrelaciones de la cerámica fenicia en el Occidente mediterráneo. Mainake, 28, s. 289-302.

Marek D.

1994 Ordynacja gołuchowska Izabelli z Czartoryskich Działyńskiej. Poznań: Muzeum Narodowe w Poznaniu.

Markoe G.

2000 Phoenicians. London: British Museum Press 
Mężyński A.

1982 Gołuchów Jana Działyńskiego. Studia Muzealne, 13, s. 74-87.

1987 Jan Działýnski 1829-1880. Wrocław: Ossolineum.

Mizera G. (oprac.), Romanowska-Zadrożna M. (red.),

2000 Straty wojenne. Sztuka starożytna. Obiekty utracone w Polsce w latach 1939-1945.

Poznań: Ministerstwo Kultury i Sztuki, Biuro Pełnomocnika Rządu ds. Polskiego Dziedzictwa Kulturalnego za Granicą.

Moscati S.

1963 La questione fenicia. Rendiconti dell'Accademia Nazionale dei Lincei, 18, s. 483-506.

1993 Nuovi studi sull'identità fenicia. Roma: Accademia Nazionale dei Lincei.

Neville A.

2007 Mountains of Silver \& Rivers of Gold: The Phoenicians in Iberia. Oxford: Oxford University Press.

Niemeyer H. G., Schubart H.

1975 Trayamar. Mainz am Rhein: Philipp von Zabern.

Núñez Calvo F. J.

2008 Estudio Cronologico-Secuencial de los materiales cerámicos de la necrópolis fenicia de Tiro-Al Bass (Líbano). Campaña de 1997. Barcelona: Universitat Pomepu Fabra.

Ownby M. F.

2012 The use of portable X-ray fluorescence spectrometry for analyzing ancient ceramics, Archaeology Southwest Magazine 26, pobrano z: https://www.archaeologysouthwest.org /pdf/pXRF_essay_ownby.pdf [dostęp 4.05.17].

Pajzderski N.

1929 Przewodnik po muzeum w Gotuchowie. Poznań: Ordynacja Książąt Czartoryskich.

Pellicer Catalán M.

2007 La necrópolis Lurita (Almuñecar, Granada) en el contexto de la colonización fenicia

Peserico A.

(=Cuadernos de Arqueolgía Mediterránea 15). Barcelona: Edicions Bella Terra.

1996 Le brocche 'a fungo' fenicie nel Mediterraneo: tipologia e cronologia. Roma: CNR.

Shackley M. S. (red.)

2011 X-Ray Fluorescence Spectrometry (XRF) in Geoarchaeology. New York: Springer.

Shugar A. N., Mass J. L. (red.)

2012 Handheld XRF for Art and Archaeology. Leuven: Leuven University Press.

Sznycer M.

1978 L'emploi des terms 'phénicien', 'punique', 'neopunique' (problèmes de méthodologie).

W: Atti del II congresso internazionale di linguistica camito-semitica (=Quaderni di semitistica 5) (s. 261-268). Florencia: Istituto di Linguistica e di Lingue Orientali.

Szymkiewicz J.

1988 Zbiory starożytności w zamku gotuchowskim. Przewodnik. Poznań: Muzeum Narodowe w Poznaniu.

Taloni M.

2016 I contatti tra Est e Ovest attraverso la cultura materiale: le oinochoai cosiddette „feniciocipriote". Forum Romanum Belgicum. Pobrano z: http://www.bhir-ihbr.be/doc/3_13_ 14.pdf [dostęp 14.04.17].

Tusa V.

1978 Relazione preliminare degli scavi eseguiti a Mozia negli anni 1972-4. W: A. Ciasca et al. (red.) Mozia 9. Rapporto preliminare della Missione congiunta con la Soprinten- 
denza delle Antichità della Sicilia occidentale (=Studi Semitici 50) (s. 7-98). Roma: Consiglio Nazionale Delle Ricerche.

Woźniak-Wieczorek A.

2015 Problematyka restytucji na przykładzie rozproszenia Kolekcji Gołuchowskiej. Santander Art and Culture Law Review, 1, s. 249-262.

Wysocka D. (red.)

2004 Izabela i Jan Działyńscy. Mecenasi kultury. Gołuchów - Kórnik: Biblioteka Kórnicka PAN, Muzeum Narodowe w Poznaniu, Ośrodek Kultury Leśnej w Gołuchowie.

\section{RESULTS OF THE X-RAY FLUORESCENCE SPECTROMETRY ANALYSES OF TWO PHOENICIAN JUGS FROM THE GOŁUCHÓW COLLECTION}

\section{S u m m a r y}

In 1895 princess Izabela Działyńska de domo Czartoryska obtained two jugs from French monk and archaeologist working in Carthage, father Alfred Louis Delattre. These artefacts, now exposed in the National Museum in Poznań, Gołuchów branch, are of clearly Phoenician origin. The jug with trefoil lip and the mushroom-lipped jug can be dated to the VII century BC due to their typological features. They have been examined by a portable X-ray fluorescence spectrometer in order to determine its chemical composition. In total 41 measurements have been taken and two analytical modes have been used. For statistical purposes eight elements have been selected: $\mathrm{Al}, \mathrm{Si}, \mathrm{K}, \mathrm{Ca}, \mathrm{Ti}, \mathrm{V}, \mathrm{Cr}, \mathrm{Fe}$. The results of two jugs are in good agreement what suggest that they could have been made from the same clay. This can be also attested by presence of uranium detected in two jugs. Unfortunately at the moment there are not enough results of spectrometric analysis to carry out a comparison of studied jugs with other examples of Phoenician pottery from Carthage. The presented outcome can serve as a contribution to Phoenician pottery database from central Mediterranean. 